\title{
Is the herb-shrub composition of veredas (Brazilian palm swamps)
} distinguishable?

\section{Diogo Pereira da Silva ${ }^{*}$, Aryanne G. Amaral ${ }^{2}$, Natália Rodrigues Bijos ${ }^{1}$ and Cássia Beatriz R. Munhoz ${ }^{1}$}

Received: May, 262017

Accepted: August, 232017

\begin{abstract}
Vereda (Brazilian palm swamp) is a poorly known savannic phytophysiognomy that occurs on moist soils with high herb-shrub floristic richness. This study aimed to document the herb-shrub species of veredas of the Estação Ecologica Serra Geral do Tocantins - EESGTO, and compare this flora with other veredas in Brazil. Furthermore, we assessed the similarity of the herb-shrub flora of the studied veredas with that of inventories of other savannas and grasslands in order to evaluate whether veredas possess an exclusive flora. Ordination analysis was performed to understand the floristic relationship among these areas. We recorded 213 species, 105 genera and 49 families at EESGTO, including five new floral records for the Cerrado and 78 for the state of Tocantins. The floristic similarity among veredas at EESGTO and the other sites was low. For all sites, a total of 1,324 species were recorded, of which 342 were unique to veredas and 187 unique to moist grasslands (campos limpos úmidos). After reviewing databases, $14.3 \%$ of these species remained exclusive to veredas and moist grasslands. The ordination analysis indicated a gradient in floristic composition from wet to dry phytophysiognomies. In conclusion, we recognize a flora that distinguishes veredas from other Cerrado phytophysiognomies.
\end{abstract}

Keywords: Cerrado, Jalapão, Mauritia flexuosa L.f., Vereda, wetlands

\section{Introduction}

The Cerrado domain occurs mainly in the CentralWest Region of Brazil. It has high levels of plant diversity and endemism, and comprises a vegetation mosaic that encompasses grasslands, savannas and forests (Mendonça et al. 2008; Ribeiro \& Walter 2008; Forzza et al. 2012). The Cerrado possesses a wide range of elevational, climatic and edaphic conditions (Oliveira-Filho et al. 1989; Silva \& Bates 2002; Klink \& Machado 2005), resulting in great variation in environmental conditions, leading to the distinct flora of its phytophysiognomies (Felfili \& Silva 1993; Munhoz \& Felfili 2007; Abreu et al. 2014).
Vereda (Brazilian palm swamp) is a humid savannic phytophysiognomy that occurs on moist soils and is characterized by a dominant herb-subshrub layer and the presence of the palm tree Mauritia flexuosa (buriti) (Ribeiro \& Walter 2008). Veredas possesses high floristic richness and diversity, which are associated with their heterogeneous environments, including differences in soil texture, organic matter and drainage, ranging from permanently flooded to well drained in the dry season (Guimarães et al. 2002; Ramos et al. 2006; Resende et al. 2013). Veredas occur throughout the entire Cerrado and are very common in the eastern portion of the state of Tocantins, especially in the Jalapão region (Villela \& Nogueira 2011).

1 Programa de Pós-graduação em Botânica, Universidade de Brasília, Asa Norte, C.P. 04457, 70919-970, Brasília, DF, Brazil
2 Instituto Internacional de Educação do Brasil, SCLN 211, 70863-520, Brasília, DF, Brazil

* Corresponding author: diogoviski@hotmail.com 
The Jalapão region encompasses a large extension of protected areas, including five conservation units, of which three are considered as strictly protected (IUCN category I) and two others classified as sustainable. The Estação Ecológica Serra Geral do Tocantins (EESGTO) is one of the three strictly protected areas, and encompasses large areas of veredas, which were used, prior to the creation of the EESGTO, as harvest areas for the extraction of the capimdourado - Syngonanthus nitens (Eriocaulaceae) floral scapes, and the buriti petiole (Arecaceae) (Schmidt et al. 2007). These species are used as raw material for handicrafts, which are commercialized throughout Brazil (Schmidt et al. 2007).

The Jalapão region is conserved primarily because of the predominance of sandy soil, which is unsuitable for agriculture, and has a low human population density (Schmidt et al. 2007). The economic activities in the region are based on extractivism, subsistence agriculture and raising livestock (Seplan 2003a; b; Schmidt et al. 2011). However, in the last decade there has been a major incentive to stimulate extensive agriculture expansion in areas of Cerrado in Tocantins (Cifuentes 2014). The decree that created Matopiba (Decree No. 8,447 of $6^{\text {th }}$ may 2015) is a good example of such incentives. This decree aimed to promote and coordinate public policies to increase agricultural production and livestock in the states of Maranhão, Tocantins, Piauí and Bahia (Brasil 2015). This agribusiness expansion in the north-northern Cerrado has led to increased rates of deforestation (Ferreira et al. 2009). Biologically, the north-northern region of the Cerrado is one of the poorest-known areas in the biome (Amaral et al. 2017), yet it experienced its highest levels of deforestation between the years 2002-2008 (Silva et al. 2006; MMA 2010). Despite the high levels of threat, the region of Serra Geral contains important protected areas for Cerrado biodiversity, such as Parque Nacional Nascentes do Parnaíba, Estação Ecológica Serra Geral do Tocantins, Parque Estadual do Jalapão and Área de Proteção Ambiental Rio Preto. The region of Serra Geral is being classified as an area of extremely high priority for conservation, with some sites being categorized as insufficiently known (MMA 2010; 2015), making this region a priority area for research and conservation.

Despite the importance of veredas for maintaining floristic diversity and water resources in the Cerrado (Araújo et al. 2002; Oliveira et al. 2009; Moreira et al. 2015), these wetlands need to be studied in order to support public policy for their conservation (Rosolen et al. 2015). There have been no evaluations of the uniqueness of the flora of veredas in relation to other phytophysiognomies. In this paper, we seek to synthesize the floristic knowledge of veredas in the Central-West Region of Brazil. Our aims were to: i) conduct a herb-shrub survey of the veredas in the Estação Ecológica Serra Geral do Tocantins; ii) synthesize the information about the floristic composition of veredas in Brazil, and iii) investigate the floristic affinities between veredas, grasslands and savannic phytophysiognomies of the Cerrado. We aimed to answer the following question: How unique is the herb-shrub flora of this humid savanna?

\section{Materials and methods}

\section{Study Area}

The study was conducted at Estação Ecológica Serra Geral do Tocantins (EESGTO), which encompasses 716,306 ha (Silva \& Bates 2002) between the eastern portion of the state of Tocantins and the western portion of the state of Bahia $\left(10^{\circ} 25^{\prime}-11^{\circ} 21^{\prime} S 47^{\circ} 13^{\prime}-45^{\circ} 50^{\prime} \mathrm{W}\right)$ (Fig. 1). The region comprises a set of depressions and adjacent plateaus forming table-mountains and inselbergs (Villela \& Nogueira 2011). The soil types are mostly characterized as Quartzipsamment (sandy soil), dystrophic and alic (Embrapa 1999; Mamede et al. 2002). According to the Köppen classification system, the climate is Aw - tropical with two distinct seasons, a dry winter (April to September) and a humid summer (October to March) (Alvares et al. 2014). The average annual temperature is around $27^{\circ} \mathrm{C}$ and the annual precipitation is about 1500-2000 mm (Seplan 2003b).

Botanical collections were carried out in five vereda sites (Fig. 1): V1- southern part of EESGTO, located on the bank of the Balsas river ( $11^{\circ} 07^{\prime} 40^{\prime \prime}$ S $\left.46^{\circ} 54^{\prime} 20^{\prime \prime} \mathrm{W}\right)$; V2- located in the Lagoa Espraiada Region (10³6’48.70”S 46³1'41.50”W); V3- located on the left bank of the Novo river, upstream view (V3; $\left.10^{\circ} 51^{\prime} 49.30^{\prime \prime S} 46^{\circ} 36^{\prime} 54.30^{\prime \prime} \mathrm{W}\right)$; V4- situated on the right bank of the Novo river, downstream view (1052'03"S $\left.46^{\circ} 36^{\prime} 55.40^{\prime \prime} \mathrm{W}\right)$; and V5- northern part of the EESGTO, located on the bank of the Preto river (10 $36^{\prime} 48.70^{\prime \prime} S$ $46^{\circ} 31^{\prime} 41.50$ ”'W).

\section{Data collection and analysis}

The floristic survey was carried out at EESGTO in the beginning (November-December 2014) and in the end (May 2015) of the wet season, when there are more herbshrub species flowering in humid environments (Munhoz \& Felfili 2005). Vascular species were recorded using random sampling following the procedure described by Filgueiras et al. (1994). Reproductive material was collected and pressed, and identified to species by experts and by comparisons with voucher specimens in the herbaria of the Instituto Brasileiro de Geografia e Estatística (IBGE) and the Universidade de Brasília (UB), where the material was incorporated. The familial circumscription followed the Angiosperm Phylogeny Group IV (APG IV 2016). Ferns identification were confirmed by the Brazilian Flora database (Flora do Brasil 2020 em construção).

A list containing families, species, vereda sites and vouchers was compiled. We evaluated the occurrences of all species sampled in EESGTO using the Species List of the Brazilian Flora database (Flora do Brasil 2020 em 

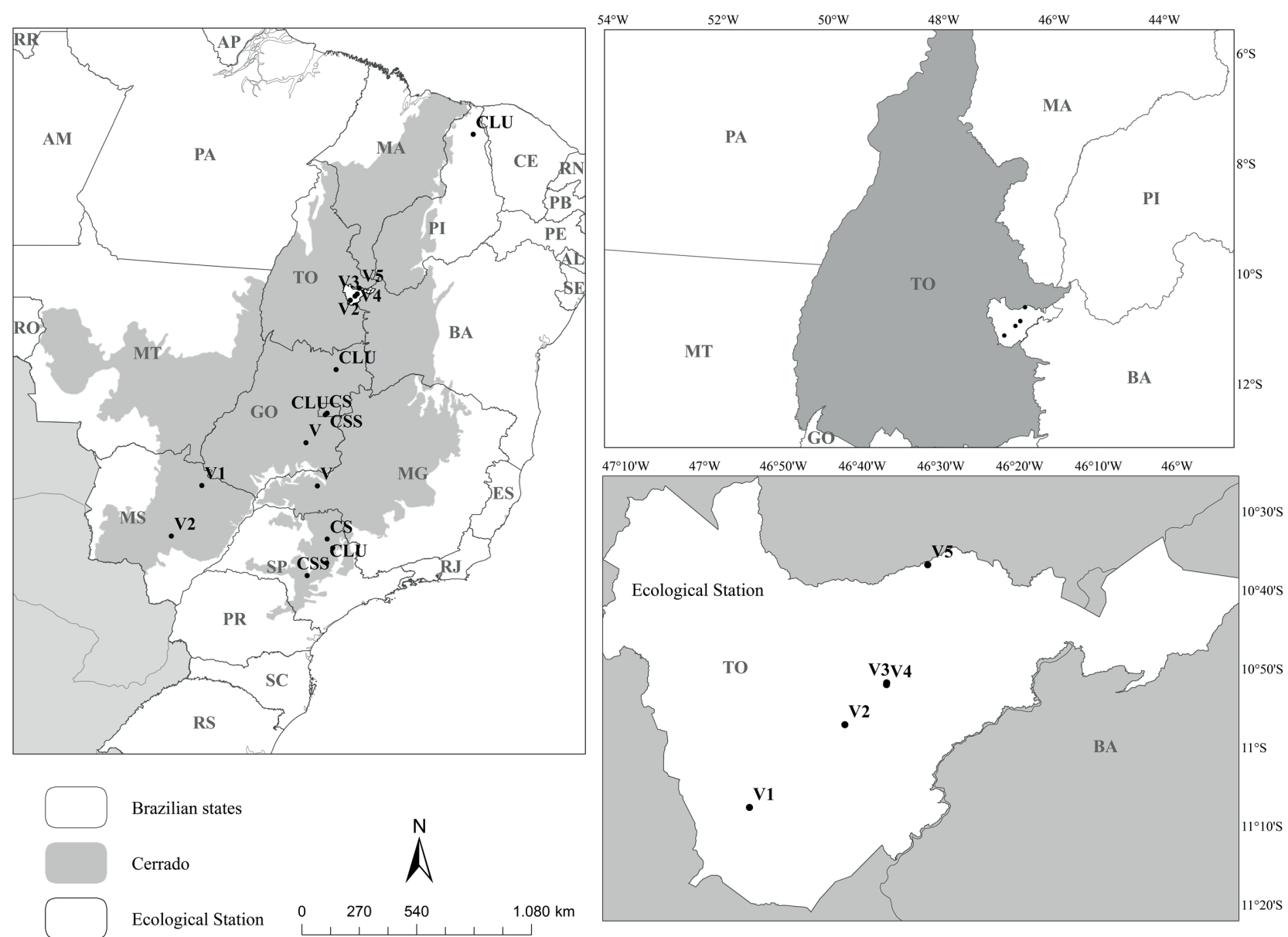

Figure 1. Location of the study sites in the Estação Ecológica Serra Geral do Tocantins, Brazil, and other Cerrado locations. The subtitle of each site are a combination of the abbreviation for the state and the phytophysiognomy: CSS = cerrado sensu stricto, CS = campo sujo (dry shrub grassland), CLU = campo limpo úmido (moist grassland) and V1, V2, V3, V4 and V5 = veredas 1, 2, 3, 4 and 5.

construção). The herb-shrub flora found in the veredas of EESGTO was compared with eight other vereda sites across Brazil (Tab. 1). Herbs, subshrubs, shrubs, palm trees and vines, classified according to Eiten (1992), were included in the list. Palm swamps occurring in areas of Mato Grosso do Sul, which are characterized by the absence of buritis (Moreira et al. 2015), were considered as moist grasslands (campo limpo úmido), according to Ribeiro \& Walter (2008).

The compiled herb-shrub flora of the veredas was compared with floristic surveys performed in dry savannas (cerrado sensu stricto) and grasslands (dry shrub grassland - campo sujo and moist grassland - campo limpo úmido), for a total of 24 areas representing a broad latitudinal range of the Cerrado (Tab. 1). Species that were identified to only the genus or family level, and species requiring confirmation (cf.), were excluded from the list. To determine if species were unique to humid phytophysiognomies, we searched SpeciesLink database (SPLink 2016) by species, and if a species had at least of 10 records in another phytophysiognomy it was not considered unique.
Floristic relationship was performed in order to compare the 13 vereda areas and the 24 other phytophysiognomies by Detrended Correspondence Analysis (DCA), using the 'vegan' package, version 2.3-1 (Oksanen et al. 2015), of R (R Development Core Team 2015). Species that appeared at only one site were excluded (McCune et al. 2002). Similarity between areas was measured using the Jaccard index. To avoid a false increase in species and floristic differences between areas, we checked all botanical names using the package 'flora', version 0.2.4 (Carvalho 2015) in R version 3.0.3 (R Development Core Team 2015).

\section{Results}

Floristic richness and composition of the herb-shrub flora of veredas in the Estação Ecológica Serra Geral do Tocantins

We collected 646 specimens from the five vereda sites of EESGTO, representing 213 species, 105 genera and 49 families 
Table 1. Cerrado phytophysiognomies compared in the present study. Cod. = Site codes; Prec. = annual mean precipitation ( $\mathrm{mm} /$ year); $\mathrm{T}$ = annual average temperature $\left({ }^{\circ} \mathrm{C}\right) ; \mathrm{N}=$ number of herbaceous vascular plant species used in the comparison matrix.

\begin{tabular}{|c|c|c|c|c|c|c|c|c|}
\hline Cod. & Sites & Phytophysiognomy & Prec. & $T$ & Latitude (S)/Longitude (W) & Altitude $(\mathrm{m})$ & References & N \\
\hline CSS_DF & $\begin{array}{c}\text { Reserva Ecológica do } \\
\text { IBGE, DF }\end{array}$ & Cerrado s.s. & 1.500 & 21 & $15^{\circ} 55^{\prime} 00.00^{\prime \prime} / 47^{\circ} 53^{\prime} 00.00^{\prime \prime}$ & 1178 & Silva \& Nogueira 1999 & 144 \\
\hline CSS_SP1 & $\begin{array}{c}\text { Reserva Pé-de-Gigante, } \\
\text { SP }\end{array}$ & Cerrado s.s. & 1.400 & 20 & $21^{\circ} 38^{\prime} 00.00^{\prime \prime} / 47^{\circ} 39^{\prime} 00.00^{\prime \prime}$ & 720 & $\begin{array}{c}\text { Batalha \& Mantovani } \\
2001\end{array}$ & 181 \\
\hline CSS_SP2, 3 & $\begin{array}{c}\text { Pratânia, Pratânia, } \\
\text { SP }\end{array}$ & Cerrado s.s. & 1.453 & 20.8 & $22^{\circ} 48^{\prime} 00.00^{\prime \prime} / 48^{\circ} 44^{\prime} 00.00^{\prime \prime}$ & 725 & $\begin{array}{l}\text { Ishara \& Maimoni- } \\
\text { Rodella } 2012\end{array}$ & 121 \\
\hline CS_SP & $\begin{array}{l}\text { Itirapina, } \\
\text { SP }\end{array}$ & $\begin{array}{l}\text { Dry shrub } \\
\text { grassland }\end{array}$ & 1.523 & 20 & $22^{\circ} 15^{\prime} 00.00^{\prime \prime} / 47^{\circ} 53^{\prime} 00.00^{\prime \prime}$ & 700 & Tannus \& Assis 2004 & 177 \\
\hline CS_DF & $\begin{array}{c}\text { Fazenda Água Limpa, } \\
\text { DF }\end{array}$ & $\begin{array}{l}\text { Dry shrub } \\
\text { grassland }\end{array}$ & 1.500 & 21 & $15^{\circ} 56^{\prime} 00.00^{\prime \prime} / 47^{\circ} 55^{\prime} 00.00^{\prime \prime}$ & 1178 & Munhoz \& Felfili 2004 & 224 \\
\hline CLU_DF & $\begin{array}{c}\text { Fazenda Água Limpa, } \\
\text { DF }\end{array}$ & $\begin{array}{l}\text { Moist } \\
\text { grassland }\end{array}$ & 1.500 & 21 & $15^{\circ} 59^{\prime} 00.00^{\prime \prime} / 47^{\circ} 58^{\prime} 00.00^{\prime \prime}$ & 1178 & Munhoz \& Felfili 2007 & 224 \\
\hline CLU_SP & $\begin{array}{c}\text { Itirapina, } \\
\text { SP }\end{array}$ & $\begin{array}{l}\text { Moist } \\
\text { grassland }\end{array}$ & 1.523 & 20 & $22^{\circ} 15^{\prime} 43.00^{\prime \prime} / 47^{\circ} 54^{\prime} 00.00^{\prime \prime}$ & 700 & Tannus \& Assis 2004 & 105 \\
\hline CLU_GO & $\begin{array}{l}\text { Alto Paraíso de Goiás, } \\
\text { GO }\end{array}$ & $\begin{array}{l}\text { Moist } \\
\text { grassland }\end{array}$ & 1.300 & 23 & $14^{\circ} 04^{\prime} 08,83^{\prime \prime} / 47^{\circ} 30^{\prime} 33,01^{\prime \prime}$ & 992 & Munhoz \& Felfili 2006 & 207 \\
\hline CLU_PI & $\begin{array}{l}\text { Parque Nacional Sete } \\
\text { Cidades Park, PI }\end{array}$ & $\begin{array}{c}\text { Moist } \\
\text { grassland }\end{array}$ & 1.650 & 26.7 & $04^{\circ} 05^{\prime} 55.26^{\prime \prime} / 41^{\circ} 42^{\prime} 09.83^{\prime \prime}$ & 290 & Mendes et al. 2014 & 92 \\
\hline V_MS1 & $\begin{array}{l}\text { Camapuã, Aquidauana, } \\
\text { Bonito, Sidrolândia, } \\
\text { Maracajú, Coxim, MS }\end{array}$ & $\begin{array}{l}\text { Moist grassland/ } \\
\text { Palm swamp }\end{array}$ & 2.000 & 25 & $18^{\circ} 58^{\prime} 52.34^{\prime \prime} / 53^{\circ} 11^{\prime} 36.86^{\prime \prime}$ & 510 & Moreira et al. 2015 & 183 \\
\hline V_MS2 & $\begin{array}{l}\text { Anhanduí, Ribas do } \\
\text { Rio Pardo, Fátima } \\
\text { do Sul, Costa Rica, } \\
\text { Chapadão do Sul, } \\
\text { Brasilândia, MS }\end{array}$ & Palm swamp & 2.000 & 25 & $21^{\circ} 07^{\prime} 26.25^{\prime \prime} / 54^{\circ} 28^{\prime} 52.15^{\prime \prime}$ & 453 & Moreira et al. 2015 & 174 \\
\hline V_GO1, 2, 3 & $\begin{array}{l}\text { Rio Peixe, Rio } \\
\text { Corumbá, Rio } \\
\text { Paranaíba, GO }\end{array}$ & Palm swamp & 2.000 & 24 & $17^{\circ} 00^{\prime} 63.00^{\prime \prime} / 48^{\circ} 47^{\prime} 33.00^{\prime \prime}$ & 899 & Resende et al. 2013 & $\begin{array}{l}152, \\
157 \\
154\end{array}$ \\
\hline $\begin{array}{l}\text { V_TM1, } 2 \text {, } \\
3,4\end{array}$ & $\begin{array}{l}\text { Clube Caça e Pesca } \\
\text { Itororó, Campo Florido, } \\
\text { Estação Ecológica do } \\
\text { Panga 1, 2, MG }\end{array}$ & Palm swamp & 1.900 & 26 & $18^{\circ} 59^{\prime} 59.00^{\prime \prime} / 48^{\circ} 18^{\prime} 00.00^{\prime \prime}$ & 860 & Araújo et al.2002 & $\begin{array}{l}246, \\
216, \\
183, \\
203\end{array}$ \\
\hline $\begin{array}{l}\text { V_TO1, 2, } 3, \\
4,5\end{array}$ & $\begin{array}{l}\text { Rio Balsas, Rio Novo } \\
\text { right bank, Rio Novo } \\
\text { left bank, Rio Preto, } \\
\text { Lagoa Espraiada, TO }\end{array}$ & Palm swamp & 1.700 & 27 & $11^{\circ} 07^{\prime} 40.00^{\prime \prime} / 46^{\circ} 54^{\prime} 20.00^{\prime \prime}$ & 490 & Current study & $\begin{array}{l}127, \\
128, \\
125, \\
133, \\
127\end{array}$ \\
\hline
\end{tabular}

(Tab. S1 in supplementary material). Nineteen species were identified to the genus level, including Bisboeckelera, which, along with Chelonanthus alatus, Paepalanthus polytrichoides, Xyris egleri and Xyris brevifolia, were new records for the flora of the Cerrado. The first four species had floristic records for the Amazon region whereas the fifth had records for the Atlantic Forest. A total of 78 new species occurrence were recorded for the state of Tocantins. The richest families in EESGTO were Poaceae (40), Cyperaceae (32), Xyridaceae (23) and Eriocaulaceae (18), which together accounted for $62.8 \%$ of the species. Rhynchospora was the most common genus in the veredas and in the other phytophysiognomies that were analyzed (Tab. S1 in supplementary material). Even though
$41 \%$ of the species occurred in a single site, the veredas of EESGTO exhibited $60 \%$ similarity according to Jaccard's similarity index. Thirty-five percent of the species occurred in all the veredas of EESGTO. Vereda site V2 was the most floristically distinct, with 29 unique species.

\section{Floristic richness and composition of the herb-shrub flora of veredas in Brazil}

Analyzing the 13 veredas from this study and the literature, we recorded 602 species (Tab. S2 in supplementary material). Only the following species were present at all sites: Andropogon bicornis, Anthaenantia lanata, Ascolepis brasiliensis, 
Ludwigia nervosa, Mauritia flexuosa and Rhynchospora globosa. The floristic similarity between EESGTO sites and the other vereda sites was low ( $22 \%$, Jaccard index). Of the 125 species of the family Poaceae included in the matrix, approximately $27 \%$ occurred in one site, while only six occurred in all 13 sites. The DCA indicated that the flora of the southeast portion of Goiás and the flora of western Minas Gerais possessed floristic affinities (Fig. 2).

\section{Floristic affinities between veradas, grasslands and savannic phytophysiognomies in Brazil}

The greatest floristic affinities (53\%) were found between veredas and moist grasslands (campo limpo úmido), followed by dry shrub grassland (campo sujo) (19.6\%) and dry savanna (cerrado sensu stricto) (14.3\%). The DCA performed in order to compare the veredas with the other types of phytophysiognomies indicated two groups, which were separated based on soil moisture and geographic distance (Fig. 3). On the first axis, humid sites appeared on the left and drained-soil sites on the right. On the second axis, the groups were separated by geographic distance.

For the 24 analyzed sites, we registered a total of 1,324 species, of which 602 occurred in veredas and 294 in moist grassland (campo limpo úmido). We recorded 342 species unique to veredas, 187 unique to moist grasslands and 710 unique to both of these vegetation types (Tab. S2 in supplementary material). However, after searching the SpeciesLink database (SPLink 2016) for records of these species in other vegetation types, we remained with 189 (14.3\%) species exclusive to only wet phytophysiognomies, $80(6 \%)$ in verdas, 59 (4.5\%) in moist grassland and 50 (3.7\%) in other phytophysiognomies.

\section{Discussion}

Floristic richness and composition of the herb-shrub flora of veredas in the Estação Ecológica Serra Geral do Tocantins

The veredas of the EESGTO showed high floristic richness, as was also found for the other veredas and moist grassland areas of the Cerrado, and with the same richest families (Poaceae and Cyperaceae) and genera (Rhynchospora and Xyris) (Araújo et al. 2002; Munhoz \& Felfili 2007; Resende et al. 2013). The floristic variation found among sites may be due to the site size, and/or differences in soil humidity among the areas, which selects species adapted to moist soil as well, where the number of species can be higher in the drained portion and reduced in the permanent flooded portion (Munhoz \& Felfili 2007).

The new occurrence records found in the veredas of EESGTO contributed to the flora of the state of Tocantins, increasing the vascular flora checklist (Mendonça et al. 2008; Forzza et al. 2012). These new records emphasize the lack of knowledge about the biodiversity in the northern/ northeastern portion of the Cerrado (Proença et al. 2010). Previously, these species had only been recorded in the Amazon and Atlantic Forest (Flora do Brasil 2020 em construção).

The wide geographic range of the Cerrado enables the sharing of species of flora between it and other Brazilian biomes (Françoso et al. 2016; Teixeira et al. 2017). The limits of the Cerrado offer the opportunity for recruitment of species from a variety of forest types of wet and dry vegetation (Simon et al. 2009). Besides the sharing of tree species between forests, the Cerrado herbaceous flora also shares many species with the Atlantic Forest, followed by the Amazon forest (Amaral et al. 2017). Moreover, it is hypothesized that the lineages of Cerrado species originated in other Brazilian biomes in the early Cretaceous period, the period of time when the Cerrado domain was formed (Ledru 2002; Pennington et al. 2004).
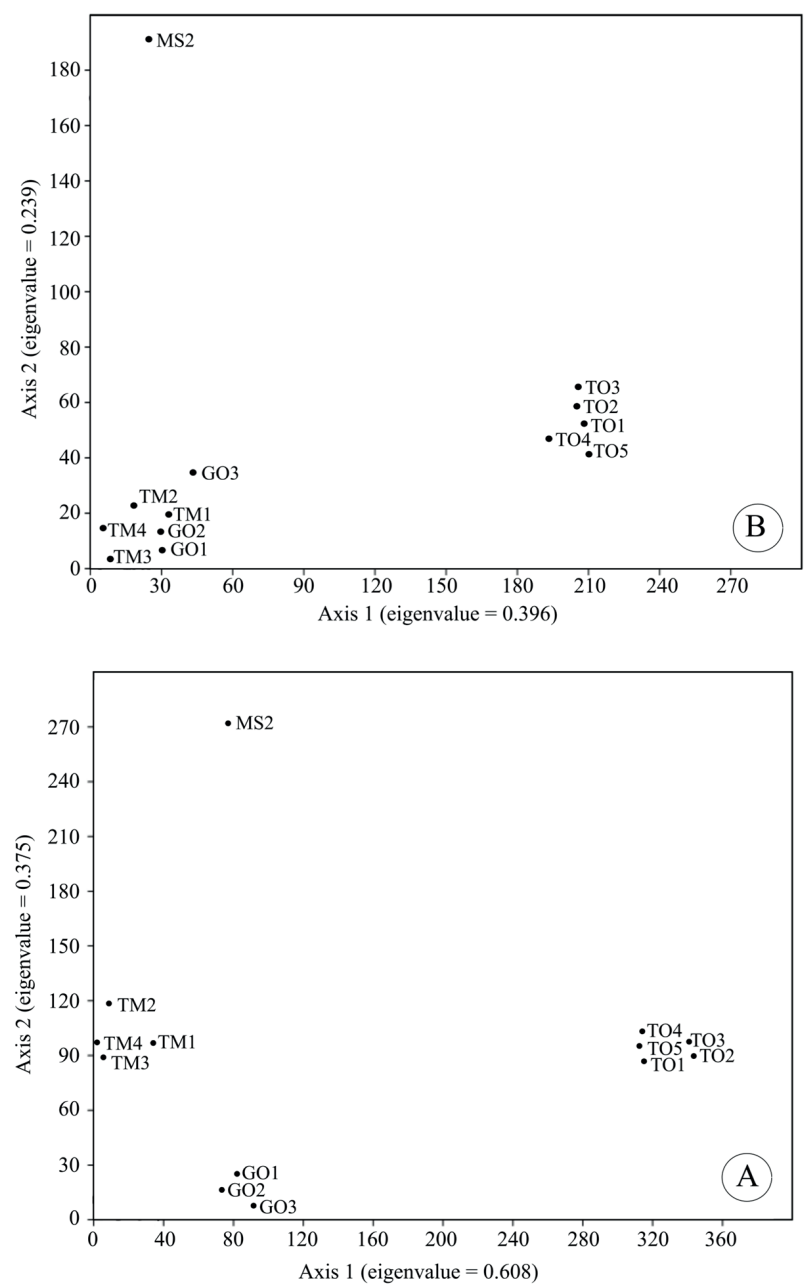

Figure 2. Positioning by axes ordination (DCA) of herb-shrub components of 13 veredas at specific (A) and generic (B) levels. MS_2 = vereda in Mato Grosso do Sul, GO_1, 2 and 3 = veredas in Goiás, TM_1, 2, 3 and 4 = veredas in Minas Gerais and TO_1, 2, 3,4 and $5=$ veredas in EESGTO. 
Floristic richness and composition of the herb-shrub flora of veredas in Brazil

The EESGTO vereda sites showed a high level of similarity in species composition, even though the number of unique species in each site was relatively high. This floristic affinity can be explained by the geographic proximity of the sites, which implies similarities in climate and soil characteristics. However, when all 13 veredas were compared they showed low floristic similarity, due to the greater geographic distances among them. This pattern has been observed for other phytophysiognomies of the Brazilian savanna that have broad longitudinal distributions and a great number of species (Ratter et al. 2003; Silva et al. 2006). In a comparison of tree composition of different sites of cerrado sensu stricto, the proximate sites showed floristic similarity, probably in response to environmental interactions (Oliveira-Filho et al. 1989).

The ordination of the vereda sites at species and genus levels showed distinct groups, with the Minas Gerais veredas being closest to those in Goiás, but the veredas of Tocantins and Mato Grosso do Sul were distant from each other. Similar patterns were found in studies that compared veredas in the same region, with neighboring sites possessing high floristic similarity (Resende et al. 2013; Moreira et al. 2015). The separation of the vereda sites highlighted the regional distinctions between them, and the fact that many species are distributed sporadically or in a mosaic (Castro et al. 1999).

\section{Floristic affinities between veredas, grasslands and savannic phytophysiognomies in the Cerrado}

Veredas and moist grassland areas were closer to each other when compared to dry savanna, and the ordination was arranged from moist sites to dry sites with low floristic sharing among the 24 areas analyzed. The herb-subshrub flora of cerrado sensu stricto was the most different when compared with the other phytophysiognomies. About $85 \%$ of the species registered for cerrado sensu stricto did not occurred in the veredas, and its flora composed $29 \%$ of the species matrix. Our study found a predictable herbaceous flora distinguishable in response to differences in edaphic characteristics and soil humidity (Munhoz \& Felfili 2007). Areas of moist grassland in the state of Piauí, which are closest to the Tocantins veredas, showed high floristic similarity when compared at the species and genus levels. In the same way, the areas of cerrado sensu stricto located in state of São Paulo and dry shrub grassland (campo sujo) located in the Federal District showed high similarity. Soil moisture acts as an environmental filter selecting species adapted to this condition (Keddy 2010). Variation in environmental factors, such as climate and soil characteristics, is usually determined by the longitudinal gradient, and is reflected in the dynamic change in distribution patterns of woody species in the Cerrado (Castro et al. 1999; Ratter et al. 2003).
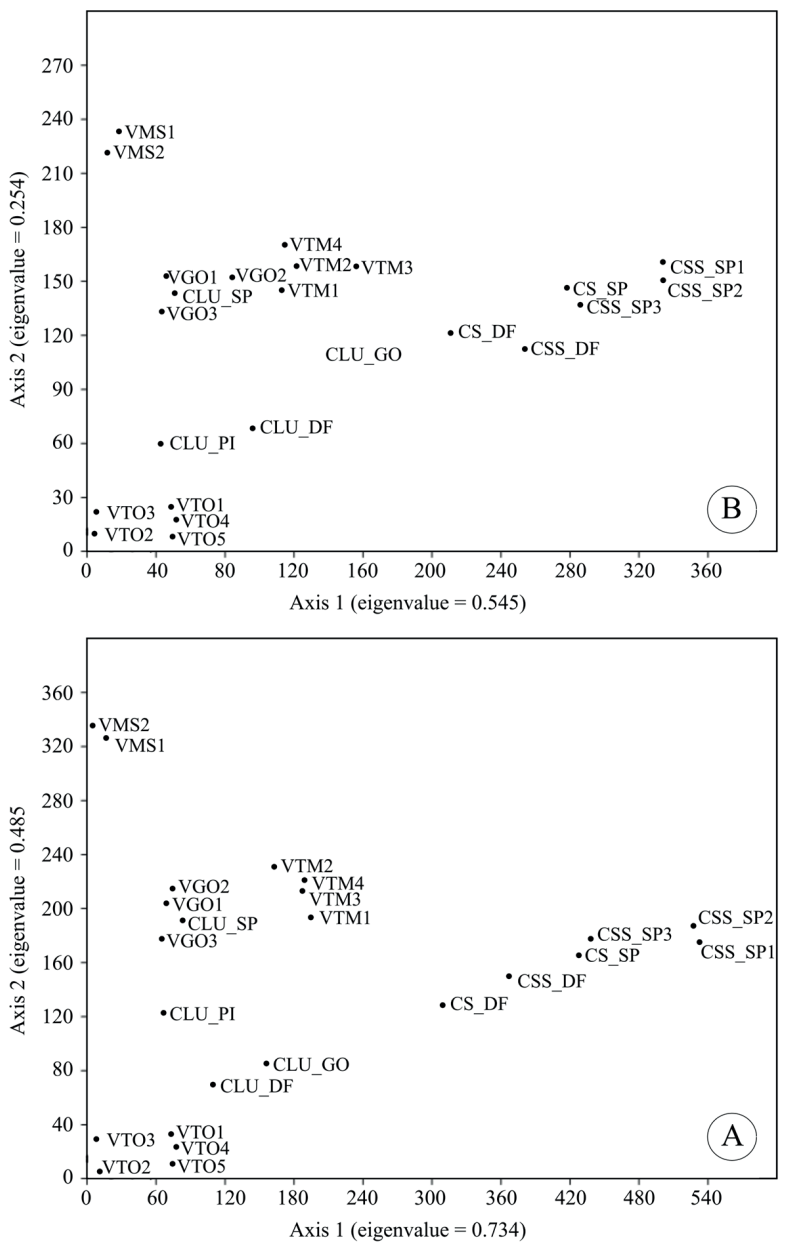

Figure 3. Positioning by axes ordination (DCA) of herb-shrub components of 24 different Cerrado phytophysiognomies at specific (A) and generic (B) levels. CSS_DF_, CSS_SP_1, 2 and 3 = sites in cerrado sensu stricto; CS_SP, CS_DF = sites in campo sujo (dry shrub grassland); CLU_DF, CLU_SP, CLU_GO, CLU_PI, V_MS_1 = sites in campo limpo úmido (moist grassland); V_MS_2, V_GO_1, 2 and 3, V_TM_1, 2, 3 and 4, V_TO_1, 2, 3, 4 and 5 = sites in veredas (palm swamps).

The occurrence of vegetation depends mainly on its formation and disturbance history over time (Ledru 2002), and floristic sharing between areas is greatly influenced by the surrounding vegetation types (Ratter et al. 2003). For example, moist grasslands (campo limpo úmido) share most of their flora with veredas, which are $47 \%$ distant floristically from any other phytophysiognomy. Thus, even though the Cerrado vegetation seems to be homogeneous, these comparisons reveal a considerable heterogeneity among environments. Nevertheless, the surrounding vegetation does not have a deep influence on the landscapes of veredas since this physiognomy provides for the establishment of plants with morpho-structural adaptations for survival in conditions of water saturation (Blom \& Voesenek 1996). Therefore, these environments have a peculiar flora that is distinct from other vegetation formations, and thus require special treatment with regard to conservation (Moreira et al. 2015). 
A high percentage of the vereda flora was considered unique, demonstrating the lack of systematic inventories in this environment. We can assume that veredas are isolated environments. The moist soil with high organic matter content works as an environmental filter that has, over time, selected a large number of species (Bijos 2017). Thus, veredas and moist grasslands had low floristic sharing and can be considered as wet islands, surrounded by savanna on well-drained soil.

Our study demonstrated that the veredas in the Jalapão region are important repositories of floral biodiversity. The region also produced new floral records for the Cerrado. The high percentage of exclusive species suggests that veredas are a distinguishable savanna, when compared to the other Cerrado phytophysiognomies. The low similarity between the vegetation of veredas and the other savanna environments reinforces their importance for consideration by public conservation policies. Our findings, therefore, suggest increased attention should be made to the conservation of veredas (Conama 2012), as well as to the moist grasslands that were very similar to them, but yet possessed their own unique flora.

\section{Acknowledgements}

We are grateful to United Nations Development Programme for their financial support, and ICMBio, especially Ana Carolina Barradas and Marco Borges. We thank CAPES for the MA scholarship granted to the first author. For the identification of botanical material the authors thank M.V. S Alves (Cyperaceae), R.C. Oliveira (Poaceae), J.B. Basava (Asteraceae), A.S. Silva (Poaceae), D.V. Segarra (several families), J.E.Q. Faria Junior (several families), Za M.R.V. (Fabaceae), V.L. Rivera (Asteraceae), C.E.B. Proença (several families), and A.L.R. Oliveira (Eriocaulaceae).

\section{References}

Abreu TAL, Pinto JRR, Mews HA. 2014. Variations in richness and tree species diversity within 14 years in a valley forest, Mato Grosso, Brazil. Rodriguésia 65: 73-88.

Alvares CA, Stape JL, Sentelhas PC, Gonçalves JLM, Sparovek G. 2014. Köppen's climate classification map for Brazil. Meterologische Zeitschrift 22: 711-728.

Amaral AG, Munhoz CBR, Walter BMT, Aguirre-Gutierrez J, Raes N. 2017. Richness pattern and phytogeography of the Cerrado's herbshrub flora and implications for conservation. Journal of Vegetation Science 28: 1-15.

APG - Angiosperm Phylogeny Group IV. 2016. An update of the Angiosperm Phylogeny Group classification for the orders and families of flowering plants: APG IV. Botanical Journal of the Linnean Society 182: 1-20.

Araújo GM, Barbosa AAA, Arantes AA, Amaral AF. 2002. Composição florística de Palm swamps no município de Uberlândia, MG. Revista Brasileira de Botânica 25: 475-493.

Batalha MA, Mantovani W. 2001. Floristic composition of the cerrado in the Pé-de-Gigante Reserve (Santa Rita do Passa Quatro, southeastern Brazil). Acta Botanica Brasilica 15: 289-304.

Bijos NR. 2017. Fatores modeladores da composição e da diversidade de espécies herbáceo-arbustivas em veredas no Brasil. MSc Thesis, Universidade de Brasília, Brasília.
Blom CWPM, Voesenek LACJ. 1996. Flooding: the survival strategies of plants. Trends in Ecology \& Evolution 11: 290-295.

Brasil. 2015. Decreto No 8.447/2015. Brasília, Casa Civil, Subchefia para Assuntos Jurídicos. http://www.planalto.gov.br/ccivil_03/_Ato20152018/2015/Decreto/D8447.htm. 07 Mar. 2016.

Carvalho G. 2015. Flora: Tools for interacting with the Brazilian Flora Checklist. R package version 0.2.4. http://CRAN.R-project.org/ package $=$ flora

Castro AAJF, Martins FR, Tamashiro JY, Shepherd GJ. 1999. How rich is the flora of Brazilian cerrados? Annals of the Missouri Botanical Garden 86: 192-224.

Cifuentes JEM. 2014. Agronegócio e acumulação por espoliação: o enclave da soja em Campos Lindos, TO. Sociedade e Estado 29: 303-304.

Conama - Conselho Nacional do Meio Ambiente. 2012. Lei no. 12.651, de 25 de maio de 2012. Brasília, Conama. http://www.planalto.gov. br/ccivil_03/_ato2011-2014/2012/lei/112651.htm

Eiten G. 1992. Formas de crescimento das plantas vasculares. In: Barros MAG. (ed.) Boletim Informativo do Herbário da Universidade de Brasília. Brasília, Universidade de Brasília. p. 6-13.

EMBRAPA - Empresa Brasileira de Pesquisa Agropecuária. 1999. Sistema Brasileiro de classificação de solos. Brasília, Embrapa-SPI, Embrapa Solos.

Felfili JM, Silva JrMC. 1993. A comparative study of Cerrado (sensu stricto) Vegetation in Central Brazil. Journal of Tropical Ecology 9: 277-289.

Ferreira LG, Ferreira ME, Rocha GF, Nemayer M, Ferreira NC. 2009. Dinâmica agrícola e desmatamentos em áreas de cerrado: uma analise a partir de dados censitários e imagens de resolução moderada. Revista Brasileira de Cartografia 61: 117-127.

Filgueiras TS, Nogueira PE, Brochado AL, GualaII GF. 1994. Caminhamento: um método expedito para levantamentos florísticos qualitativos. Cadernos de Geociências 12: 39-43.

Flora do Brasil 2020 em construção. Rio de Janeiro, Jardim Botânico do Rio de Janeiro. http://floradobrasil.jbrj.gov.br. 24 May. 2016.

Forzza RC, Baumgratz JFA, Bicudo CEM, et al. 2012. New Brazilian floristic list highlights conservation challenges. BioScience 62: 39-45.

Françoso RD, Haidar RF, Machado RB. 2016. Tree species of South America central savanna: endemism, marginal areas and the relationship with other biomes. Acta Botanica Brasilica 30: 78-86.

Guimarães AJM, Araújo GM, Corrêa GF. 2002. Estrutura fitossociológica em área natural e antropizada de uma vereda em Uberlândia, MG. Acta Botanica Brasilica 16: 317-329.

Ishara KL, Maimoni-Rodella R. 2012. Richness and similarity of the Cerrado vascular flora in the central west region of São Paulo state, Brazil. Check List 8: 32-42.

Keddy PA. 2010. Wetland ecology: Principles and conservation. Cambridge, Cambridge University Press.

Klink CA, Machado RB. 2005. Conservation of the Brazilian Cerrado. Conservation Biology 19: 707-713.

Ledru MP. 2002. Late Quaternary history and evolution of the Cerrado as revealed by palynological records. In: Oliveira PS, Marquis RJ. (eds.) The Cerrados of Brazil: ecology and natural history of a neotropical savanna. New York, Columbia University Press. p. 33-50.

Mamede F, Garcia PQ, Sousa Júnior WC. 2002. Análise da viabilidade sócio-econômico-ambiental da transposição de águas da bacia do rio Tocantins para o rio São Francisco na região do Jalapão/TO. Caderno de política ambiental, 1. Brasília, Conservation Strategy Fund/Conservation International do Brasil/ Instituto Internacional de Educação do Brasil.

McCune B, Grace JB, Urban DL. 2002. Analysis of ecological communities. Oregon, MJM Press.

Mendes MRA, Júnior S, Castro AAJF, Takahashi FSC, Munhoz CBR. 2014. Temporal change in species and functional plant traits in the moist grassland on the Sete Cidades National Park, Piauí, Brazil. Brazilian Journal of Biology 74: 111-123.

Mendonça RC, Felfili JM, Walter BMT, et al. 2008. Flora vascular do bioma Cerrado. In: Sano SM, Almeida SP, Ribeiro JF. (eds.) Cerrado: ecologia e flora. Brasília, Embrapa-Cerrados, Embrapa Informação Tecnológica. p. 1279. 
MMA - Ministério do Meio Ambiente. 2010. Plano de Ação para prevenção e controle do desmatamento e das queimadas no Cerrado: conservação e desenvolvimento. Brasília, MMA.

MMA - Ministério do Meio Ambiente. 2015. Áreas Prioritárias - mapas por bioma. Brasília, MMA. http://www.mma.gov.br/biodiversidade/ biodiversidade-brasileira/\%C3\%A1reas-priorit\%C3\%A1rias/item/489. Apr. 2015.

Moreira SN, Eisenlohr PV, Pott A, Pott VJ, Oliveira-filho AT. 2015. Similar vegetation structure in protected and non-protected wetlands in Central Brazil: conservation significance. Environmental Conservation 42: 356-362.

Munhoz CBR, Felfili JM. 2004. Composição florística do estrato herbáceosubarbustivo em uma área de campo sujo na Fazenda Água Limpa no Distrito Federal, Brasil. Boletim do Herbário Ezechias Paulo Heringer 13: 85-113.

Munhoz CBR, Felfili JM. 2005. Fenologia do estrato herbáceo-subarbustivo de uma comunidade de campo sujo na fazenda água limpa no Distrito Federal, Brasil. Acta Botanica Brasilica 19: 981-990.

Munhoz CBR, Felfili JM. 2006. Floristics of the herbaceous and subshrub layer of a moist grassland in the Cerrado biosphere reserve (Alto Paraíso de Goiás), Brazil. Edinburgh Journal of Botany 63: 343-354.

Munhoz CBR, Felfili JM. 2007. Florística do estrato herbáceo-subarbustivo de um campo limpo úmido em Brasília, Brasil. Biota Neotropica 7: 205-215.

Oksanen J, Blanchet FG, Kindt R, et al. 2015. Vegan: Community ecology package. R package version 2.0-10. http://CRAN.R-project.org/ package $=$ vegan

Oliveira GC, Araújo GM, Barbosa AAA. 2009. Florística e zonação de espécies vegetais em veredas no Triângulo Mineiro, Brasil. Rodriguésia 60: 1077-1085.

Oliveira-Filho AT, Shepherd GJ, Martins FR, Stubblebine WH. 1989. Environmental factors affecting physiognomic and floristic variation in an area of cerrado in central Brazil. Journal of Tropical Ecology 5: $413-431$.

Pennington RT, Lavin M, Prado DE, Pendry CA, Pell SK, Butterworth CA. 2004. Historical climate change and speciation: neotropical seasonally dry forest plants show patterns of both Tertiary and Quaternary diversification. Philosophical Transactions of the Royal Society of London B: Biological Sciences 359: 515-538.

Proença CEB, Soares-Silva LH, Silva PIT, Fank-de-Carvalho SM. 2010. Two new endemic species of Myrtaceae and an anatomical novelty from the Highlands of Brazil. Kew Bulletin 65: 463-468.

R Development Core Team. 2015. R: a language and environment for statistical computing. Vienna, R Foundation for Statistical Computing.

Ramos MVV, Curi N, Motta PEF, Vitorino ACT, Ferreira MM, Silva MLN. 2006. Palm swamps do Triângulo Mineiro: solos, água e uso. Ciência e Agrotecnologia 30: 283-293.

Ratter JA, Bridgewater S, Ribeiro JF. 2003. Analysis of the floristic composition of the Brazilian cerrado vegetation III: comparison of the woody vegetation of 376 areas. Edinburgh Journal of Botany 60: 57-109.

Resende ILDM, Chaves LJ, Rizzo JA. 2013. Floristic and phytosociological analysis of palm swamps in the central part of the Brazilian savanna. Acta Botanica Brasilica 27: 205-225.

Ribeiro JF, Walter BMT. 2008. As principais fitofisionomias do bioma Cerrado. In: Sano SM, Almeida SP. (eds.) Cerrado: ecologia e flora. Brasília, Embrapa. p. 153-212.

Rosolen V, Oliveira DA, Bueno GT. 2015. Vereda and Murundu wetlands and changes in Brazilian environmental laws: challenges to conservation. Wetlands Ecology and Management 23: 285-292.

Schmidt IB, Figueiredo IB, Scariot A. 2007. Ethnobotany and effects of harvesting on the population ecology of Syngonanthus nitens (Bong.) Ruhland (Eriocaulaceae), a NTFP from Jalapão region, Central Brazil. Economic Botany 61: 73-85.

Schmidt IB, Mandle L, Ticktin T, Gaoue OG. 2011. What do matrix population models reveal about the sustainability of non-timber forest product harvest? Journal of Applied Ecology 48: 815-826.

Seplan - Secretaria de Estado de Planejamento. 2003a. Plano de Manejo do Parque Estadual do Jalapão. Palmas, Seplan. www.seplan.to.gov.br

Seplan - Secretaria de Estado de Planejamento. 2003b. Zoneamento Ecológico Econômico de Tocantins. Palmas, Seplan. www.seplan. to.gov.br

Silva JF, Fariñas MR, Felfili JM, Klink CA. 2006. Spatial heterogeneity, land use and conservation in the cerrado region of Brazil. Journal of Biogeography, 33: 536-548.

Silva JMC, Bates JM. 2002. Biogeographic patterns and conservation in the South American Cerrado: A tropical savanna hotspot the Cerrado, which includes both forest and savanna habitats, is the second largest South American biome, and among the most threatened on the continent. BioScience 52: 225-234.

Silva MD, Nogueira PE. 1999. Avaliação fitossociológica do estrato arbustivoherbáceo em cerrado stricto sensu após incêndio acidental, no Distrito Federal, Brasil. Boletim do Herbário Ezechias Paulo Heringer 4: 65-78.

Simon MF, Grether R, Queiroz LP, et al. 2009. Recent assembly of the Cerrado, a neotropical plant diversity hotspot, by in situ evolution of adaptations to fire. Proceedings of the National Academy of Sciences of the United States of America 106: 20359-20364.

Tannus JL, Assis MA. 2004. Vascular species composition of dry and swamp grasslands in a savanna area, Itirapina-SP, Brazil. Brazilian Journal of Botany 27: 489-506.

Teixeira AMC, Pinto JRR, Amaral AG, Munhoz CBR. 2017. Angiosperm species of "Cerrado" sensu stricto in Terra Ronca State Park, Brazil: floristics, phytogeography and conservation. Brazilian Journal of Botany 40: 225-234.

Villela FNJ, Nogueira C. 2011. Geologia e geomorfologia da estação ecológica Serra Geral do Tocantins. Biota Neotropica 11: 217-230. 